(c) 2022 by Emerald Publishing Limited. This AAM is provided for your own personal use only. It may not be used for resale, reprinting, systematic distribution, emailing, or for any other commercial purpose without the permission of the publisher Accepted version downloaded from SOAS Research Online: http://eprints.soas.ac.uk/35153

https://doi.org/10.1108/S0190-128120210000041001

FINAL ACCEPTED DRAFT, PLEASE QUOTE AS FOLLOWS:

Bowles, Ben, Bayliss, Kate and Elisa Van Waeyenberge (2021), London's "Super Sewer": A case study for the interdisciplinary possibilities of anthropologists and economists investigating infrastructure together, Research in Economic Anthropology 41

\title{
London's "Super Sewer": A case study for the interdisciplinary possibilities of anthropologists and economists investigating infrastructure together
}

\begin{abstract}
Despite the fact that recent anthropological interest in infrastructure has done much to illuminate the infrastructure asset as an assemblage of actors, technologies and ideas, an interdisciplinary approach is required to unpack how the infrastructure project comes together as an assemblage and the role that financial technologies and discourses play in shaping it. Here an interdisciplinary approach is applied to a novel infrastructure asset, London's Thames Tideway Tunnel, in order to show how multiple actors and visions of the world are brought together to make the infrastructure asset come to fruition. The paper concludes that this interdisciplinary approach to infrastructure can allow us to keep multiple sides of the infrastructure project in sight simultaneously. This includes both the creation of a rhetorical vision and spectacle around the asset, and the underlying financial arrangements that bind it together. If we do so, we can understand how new infrastructural forms utilise particular financial technologies and ideas to change the relationship between the public and the private, between consumers and providers, and act towards the creation of a new "public good" that normalises private provision.
\end{abstract}

\section{Section 1: Interdisciplinary Encounters}

Anthropology has gained much, in recent years, from turning to consider infrastructures as assemblages - as comings together of actors, ideas, regimes of expertise, and technologies (see Larkin, 2013: 330). Penny Harvey and Hannah Knox's (2012) ethnography of road building in Peru is an instructive example of the benefits of this approach as, in their analysis, infrastructure does not simply appear, where present, as some kind of state-imposed monolith, or where absent, as representative of state neglect. Infrastructures, rather, are emergent forms, created by unstable agglomerations of financiers, politicians, engineers and publics, all with rather different (and possibly competing) visions of the world. Furthermore, infrastructures are an important way in which the public good is (re)formulated (see also Bear and Mathur, 2015) and the morality of different forms of provision is debated.

In their work, Harvey and Knox describe infrastructure as "sociotechnical [sic] assemblages through which it is possible to tease out the arrangements of people and things and ideas and materials that make up larger technological systems" (Harvey and Knox, 2015: 5). Their approach, therefore:

"attends to the imaginative and material processes that contribute to the emergence the coming into being - of infrastructures as open-ended structural forms. Included in 
this are multiple and often incompatible aspirations, technical procedures, organisational dynamics, employment relations, health and safety regulations, property regimes, and understandings of the "public good"' (Harvey and Knox. 2015: 6).

Such a focus on infrastructure from a number of complementary angles, in terms of a project as a coming together of actors and ideas (and the way in which it draws people together and creates new imaginaries) and not just on the asset as it exists on the ground, allows us to understand not just what infrastructure is, what it means, or what it does to people, but also why it is there in the first place, who has driven a particular infrastructure intervention, and to what ends.

There are, however, gaps and unexplored spaces even in these recent anthropological approaches to infrastructure. Specifically, the financing story and the particular power of financiers and financial logics has not yet been widely explored through deep engagement with investors and financial elites. Bear's ethnography of infrastructure in the Port of Kolkata deals with changes in infrastructure through an analysis of debt and austerity logics and their effects (Bear, 2015), Simpson aims to track the financial flows through road infrastructure projects in South East Asia (Simpson, forthcoming; see also The Roads Project, n.d) and Harvey and Knox mention global financiers, specifically stating that "infrastructural engineering projects are supported by international flows of capital" (Harvey and Knox, 2015: 168) and that "projects are funded through a mix of public funds and private capital" (ibid:168). None of the above, however, push these understandings into a thorough articulation of the structure and internal logics of international capital, investors, and financiers.

This relative lacuna in the literature has been recognised by authors who have called for a critical anthropology of the economy, focused on actors at all levels of power (see Bear et al., 2015). There have been some excellent recent interventions where anthropology has approached global financial elites (Ouroussoff, 2010; Ho, 2009), particularly looking at how these (re)shape the world through their understanding of risk and uncertainty. The infrastructure "ecosystem" of pension companies, insurers, private equity firms, raters, investment managers, and lawyers is highly complex, with each of these groups having their own distinct understandings and perspectives. All of this means that the finance angle of infrastructure (given that the ideas, expertise, and governance angles are well described) is an area that remains yet to be fully explored through interdisciplinary engagement with the political economy. Political economists have expertise in excavating financial relationships and in understanding the logics through which financial actors approach the world and, as such, have the potential to offer to anthropology a fresh perspective on questions of infrastructure provision.

This is not to say that anthropologists have not begun the important work of tying together finance, capital and infrastructure in their ethnographies. A number of studies of infrastructures have begun to conceptualise of infrastructures as both things in and of themselves and also as conditions of possibility for other relations and effects to come into being. A key prompt to this is Susan Leigh Star's call for us to attend to the "when" of infrastructure; why this project at this particular time? Who benefits from a project and what, crucially, is transformed by its imposition on the environment (Star, 1999)? We therefore consider our work to be continuing the productive and novel approach of anthropologists such as Hannah Appel who, based on her fieldwork projects in the energy sector in Equatorial Guinea, argues for an ethnography of "the national economy" that reveals how such a concept as the economy itself is produced through deliberately constructed imaginaries, the power and logics of international capital, and the imposition of spectacular infrastructure projects and other power-laded spending interventions. She suggests that "to take the economy seriously in part means to take seriously people's fantasies about it" (Appel, 2017:312) - an approach that underpins the ethnographic sections of this paper. Another pivotal figure is Brenda Chalfin, whose ethnography of neoliberal restructuring in Ghana demonstrates how the demands and logics of finance, as experienced in her fieldwork within Ghana's Customs Office, transformed the material world of the nation, its state apparatuses, as well as its position in global politics (Chalfin, 2010). However, more work is 
still needed, generated from other field sites and spaces, to better explore the complicated interplay between States, infrastructure projects, and capital.

Thus, it is here contended that the study of infrastructure finance benefits from an interdisciplinary engagement. Concepts drawn from economics and political economy can help us to understand not just how meaning emerges and is attributed to particular economic and infrastructural interventions, but also how specific infrastructural interventions change relationships between individuals, communities, collectivities, states, corporations and other private agents, with attendant redistributions of power and resources. The distributional effects of infrastructure - not just what does a road or a water tap do for people, but how does the way in which it is financed affect their lives, maybe outside of their immediate understanding - can be assumed by some as being outside of anthropology's remit, but with frames taken from political economy, we can add these distributional effects into our ethnographies of infrastructure. Infrastructures appear as more than physical or even physical and ideological interventions, they are also financial interventions, tying people's money, through taxes or charges, into global relationships of exchange and redistribution, as the ethnographies of infrastructure, capital and the State in Bear (2015), Appel (2017) and Chalfin (2010) make abundantly clear.

Anthropology in turn adds depth to political economy, to unpack the narratives and meanings associated with infrastructure and how these may differ between actors; be they actors in finance, construction companies, the state, end users, or tax payers. Similarly, economics (or political economy) provides to anthropology an attention to financial and fiscal flows, so that anthropology can gain appreciation of the distributional impacts and wider issues that result from infrastructure provision, such as on labour effects and effects on regional development. This will result in a richer understanding of what infrastructure is, what its effects are, and who are the winners and losers in an enfolding set of relationships.

It is therefore important to combine anthropological conceptualisations of infrastructure as sites "through which politics is translated from a rationality to a practice in all its social, material and political complexity" (Appel et al. 2018: 20) with a political economy analysis that draws attention to underlying economic and financial realities (understood as structured and with systemic features) so that we can account for the way in which specific infrastructure projects take form, are implemented and produce particular outcomes.

The paper deploys a practice of interdisciplinarity that does not simply ask what anthropological perspectives add to an economist's explanatory framework (as in other projects on which I have worked where the perspective from outside of anthropology is that the ethnographer is best used ad hoc to "add the people in" instead of contributing to the heart of the analysis), nor does it rest in anthropology and try to add a few economic concepts to the social anthropologist's traditional mix, another fault that I have observed in some projects that claim interdisciplinary credentials. Rather, it seeks to use a set of heuristic tools, with their origins in both disciplines to investigate an emergent form such as an infrastructure project from a number of complementary angles. It seeks to approach the infrastructure from both the public facing front stage and the organisational back stage (spaces that require more detailed excavation such as interviews with stakeholders and rooting through company accounts). In the words of Barthes:

"Interdisciplinary work, so much discussed these days, is not about confronting already constituted disciplines... To do something interdisciplinary it's not enough to choose a "subject" (a theme) and gather around it two or three sciences. Interdisciplinarity consists in creating a new object that belongs to no one." (Barthes, R. quoted in, J. "Partial Truths.” In (J. Clifford and G. Marcus eds.) Writing Culture, 1986.) 
This paper does not seek simply to take infrastructure as an object and approach it separately as anthropologists and as economists and add our accounts together in a "this and that" fashion. Rather, it looks at an infrastructure system as one of Barthes' new objects, and observe, using the tools at our disposal and sharing our methods (the entire team interviewed participants and completed archival work together) how different parts of it fit together to make a whole. Therefore, the financing "side" of the project was revealed not just as a coming together of economics ideas (Pike et al, 2019; Loftus and March, 2017), but rather also includes charisma and processes of integration and consensus building much of the type that anthropologists of major projects have identified (Bear, 2019:16; Evans, 2016). As shall be seen, all of these techniques, ideas and technologies, along with political science ideas of the "public good", are integral to making a successful financial vehicle for infrastructure. Further, when looking at the impacts of infrastructure on communities, it is possible to see not only material effects in the built environment (that may well be disruptive and radically transformative, as Dalakaglou (2010) and others in anthropology have pointed out), but also radical distributive effects, visible only by following economic flows, that may well otherwise be missed without careful following and investigation of financial flows and the complex nesting inter-relationships of shell companies within an infrastructure project's organisational chain.

\section{Section 2: Thames Tideway Tunnel - A Case Study}

\section{Introducing The Thames Tideway Tunnel}

This rest of the paper demonstrates how such an interdisciplinary approach to infrastructure, with the finance story at its heart, may function. This is done through the case study of London's " $£ 5$ bn super sewer" (The Five Billion Pound Super Sewer, 2019); the Thames Tideway Tunnel [hence Tideway]. Tideway is a tunnel, actually costing $£ 4.2 \mathrm{bn}$, under the river Thames that has been designed to carry overflow from London's existing and largely Victorian sewer system to the Beckton pumping station in the East End of London and from there to the sea (Loftus and March, 2017: 1). It is designed to stop overflows of sewage into the River Thames. A prime driver for the project was the threat of European Union litigation over breaches of water quality standards, and therefore it could look on the surface like a technical solution to a practical environmental problem. However, as shown in the following sections, the way in which Tideway is designed and implemented (as a particular way of addressing an environmental problem chosen against alternatives and also as a financial and organisational object) is due to much larger forces and is about a lot more than a technical solution to a sewage issue.

This paper presents findings from two research periods. The first is research conducted by myself ${ }^{1}$ and Prof. Laura Bear as part of a study into the resilience of infrastructure in which we were working as partners of the UK Government's Cabinet Office. ${ }^{2}$ This project allowed Professor Bear and I the opportunity to interview key members of infrastructure projects, and our mutual interest in the River Thames led us to concentrate on executives working on the Tideway project (Bear, 2019). It became

\footnotetext{
${ }^{1}$ As this paper was originally drafted by the first author and partially presents fieldwork from before his engagement with the co-authors, it uses the first-person pronoun where appropriated. The co-authors were responsible for re-drafting and additional content in sections 1 and 3.

${ }^{2}$ This project was hosted at the LSE and funded as a pilot project for UCL's CRUISSE (Confronting Radical Uncertainty in Science Society and the Environment) network. In building a report for the UK Government Cabinet Office on the resilience of infrastructure, we gained access to financiers, government bureaucratic actors (mainly civil servants) and infrastructure project executives. I also had the opportunity to observe a small number of meetings between infrastructure executives, regulators and government representatives. Their names of participants and the exact details of these meetings have been anonymised here and every measure has been taken to make participants unidentifiable in the literature.
}

4 of 22 
clear to Professor Bear and I that Tideway was both a fascinating assemblage of interests and organisations, much as the new anthropology of infrastructure described above would recognise. It was, however, also clearly reflective of a new set of financial ideas and technologies, demonstrating the direction in which infrastructure financing in the UK was heading in the context of the decline of the UK Government's Public Private Partnership model and specifically its use of the Private Finance Initiative (PFI) and its successor PF2 (Loftus and March, 2017). This work was continued and contextualised in an interdisciplinary project at SOAS. ${ }^{3}$ Through interviews with members of the infrastructure finance community, attendance at industry events, and observing the interactions between financiers and actors from the government (the National Infrastructure Commission, the Infrastructure and Projects Authority, and the Treasury), our project team came to appreciate how the interconnecting perspectives of these powerful actors shape infrastructure projects.

I examine Tideway as a vision and a spectacle, before examining it as a coming together of financial logics and as an object that leads to further financialisation of the water sector. In doing so, I show how Tideway, as an example of a new and emerging kind of infrastructure mega-project, may be fundamentally reshaping the world, physically, financially, and in terms of the "public good".

\section{Thames Tideway Tunnel as vision and spectacle}

A project of the transformative scale of Tideway needs to exist as a set of relationships and alliances (between people and organisations) and must be surrounded by a rhetorical argument for its existence in the form of a powerful imaginary or vision. There needs to be a spectacle created around the infrastructure project that creates a sense of success and confidence, both back-stage, facing potential investors, and front-stage in the realm of what would traditionally be called "public relations" or "engagement." However, the separation between these representations to audiences is not total. Infrastructure CEOs, as Bear describes them $(2015 ; 2019)$ are charismatic figures who can pull together investors, publics, experts, and politicians with a vision that is projected or emphasised a little differently for all of these disparate actors. Tideway presented a complex and historically and symbolically rich vision to those that encountered it, be they residents who needed to be re-sited to make space for Tideway's works, potential investors, government bureaucratic actors, the engineering community, or a general interested public. The vision and the spectacle around it, created through engagement, events and partnerships, together present Tideway as an emergent object that is designed to seem positive, progressive, reliable, and inevitable.

The unfolding project needs to bring onboard all those it reaches, including and especially, potential dissident and critical voices. Tideway and mega-projects like it (see Evans, 2016) are machines for consensus, creating utopian visions of the future that are hard to criticise: they are designed to appear as obvious bringers of manifold goods. More than this, through building consensus, these projects remove the possibility of dissent and de-politicise assets that are evidently political interventions. Over the course of this fieldwork with Tideway Executives and with large-scale infrastructure professionals more broadly, I came to think of such projects as a little like "The Blob" from the 1958 Science-Fiction film; inevitable, inescapable, becoming larger and stronger as they bring more and more people and things into their bodies. I proceed by describing, first, the kinds of "behind the scenes" bringing together and consensus building that Tideway relies on and, secondly, the imaginaries and spectacles that can emerge from such agglomerations of actors with aligned interests what Bear (2019: 16) calls the "glinting surfaces" of infrastructure projects.

\footnotetext{
${ }^{3}$ This second project "Trajectories of Infrastructure Finance" was hosted at SOAS Department of Economics and funded through NIESR's Re-building Macro-economics project, and specifically the Macroeconomic Institutions hub. We had the opportunity to interview members of the investment finance community, regulators and civil servants and to attend infrastructure industry events. All identifying details from these have been anonymised, with special care to make all material from events and interviews that occurred under the Chatham House rule unidentifiable.
}

5 of 22 


\section{Consensus and Charisma}

Bear (2015) describes the ways in which particular charismatic actors with a vision of a prosperous future which they can convince others to "buy into" are the true nodes of power in a contemporary capitalism that has become dominated by speculation. The ways in which charismatic actors can formulate dreams of success and transformation and create widespread "buy-in" for these projects through the power of their envisioning is also explored to great effect by Tania $\mathrm{Li}$ in her ethnography of development projects in Indonesia (Li, 2007). In Bear and Li's ethnographies, speculation appears as both a form of capitalism with its particular technologies, but is also a way of envisioning the world; conjuring up images of affluent futures, and often evoking affluent pasts. This was both a feature of Bear's ethnography of the Port of Kolkata, and also of the fieldwork we conducted together on the River Thames in London (Bear, 2019).

The power of charisma in action was demonstrated when Professor Bear and I met David Walters ${ }^{4}$, Tideway's "Key Engineer-Manager" (ibid: 16) David was particularly well suited to running a consensus-building machine such as an infrastructure mega-project. Bear describes him as "a man of limitless enthusiasm and persuasion" (ibid); exactly the suite of skills necessary to create a novel assemblage of actors behind the scenes of a major infrastructure project. As Patrick Joyce described (Joyce, 2003), the development of modern Liberal governance relies on ideologies of connection and access, with contemporary Liberalism having emerged in concert with technologies of connection and networking. Modern infrastructure project managers are experts in skilfully initiating and managing these connections across multiple domains, agencies and types of actor.

David and his team were able to bring together the investment community, bureaucratic actors from the UK Government, regulators, water company executives, and engineers in the back and board rooms of the project. In participant observation at some of Tideway's meetings with regulators and government stakeholders, I saw first hand how meetings and consultations (as Evans, 2017 describes) can be used to build consensus. The official format of minutes and actions flatten potential disputes, with silence/non-engagement standing for consensus and agreement in the official records. Not that there was much dispute evident, as these executives, charmed and engaged by David and his charismatic team from the inception of the project were mainly approving of or silent regarding Tideway's actions. Many of these actors had known each other from years engaged together in the water industry. Some had worked in both water companies and in water regulation, demonstrating how the sector has a "revolving door" between companies, regulators and government (Bayliss, 2017).

More than these backroom actors, however, brokers like David need to involve outside actors, especially those who may otherwise be critical, in order to keep the consensus machine rolling onwards. This 'consensus machine' also operates to defuse potential objection through taking care to align potentially critical actors through whatever means seem practicable. Bear quotes David saying that: "We want to create a situation where everyone wants you to succeed... We wanted to tailor the responses of academics, neighbours, politicians, newspapers, and the public." He goes on to use the example of the charity Thames 21. It was "a visible supporter of the river, a charity" (Bear, 2019: 17) stating that "at first the TTT was a dangerous entity to them, so we continued to support Thames 21 financially and voluntarily. They would not take office space from us as they would have been seen as too close, but now we go for awards together" (ibid.). In this way, slowly, critical others are bought into a growing consensus.

Such consensus building and its role in the defusion and management of objection is further extended to publics who may be affected by changes and therefore must be engaged. David talked about "frontloading benefit" to these communities to show them what they would gain from Tideway's presence;

\footnotetext{
${ }^{4}$ Here is am continuing to use the pseudonym for this particular participant that Bear used in Bear (2019). 6 of 22
} 
"Not just building something to replace their park or pier after we have taken it down, but building it first, before our works begin." Critical communities were to be "overcompensated," if displaced by works then put up in expensive hotels whilst the construction was carried out. David described this as having an economic benefit to the project; costly legal battles in the future can be prevented by giving affected communities more now.

Bear writes about David that she "realised there could be no limits to these plays of glinting surfaces and hidden depths [that David is able to conjure]...." and that "this play deflects attention from the financial contracts that organise accumulation, while it also creates the complicities and expansive potential that makes these techne profitable" (ibid.). David and his fellow executives are at the centre of an expanding network. Central to the skillset required for their job is the ability to bring together and make consensus for such a project inevitable, and the idea of consensus against a project practically unthinkable.

Evans describes a situation in which those against or trying to mitigate the effects of a major infrastructural intervention (in this case the London Olympic Games in 2012) had to build a dense interpersonal network of contacts in various different organisations and familiarise themselves with new tools of representation. She summarises how this represents "a new kind of political action" and notes that "it takes the form of years of painstaking work, cultivating... behind-the-scenes, informal relationship[s]" (Evans, 2017:130). She also notes the turn to "documentary and diplomatic tools" (ibid.) involved in becoming such a political actor. From this I take the idea that successful political action in the world of speculative mega-projects involves the ability to create consensus and communities through "engaging" "stakeholders." It is a race between project promoters and opponents to put such a consensus-machine into operation. However, such a machine does not just consist of people brought together, they must be brought together around a compelling vision of the world as it will be transformed; often a vision with particular spectacular expressions.

\section{Vision and Rhetoric}

As a summary of the ideas folded into Tideway shows, the rhetoric around Tideway consists of an imaginary of the potential utopian benefits of the tunnel, calling into a prosperous future, but using many images rooted in London's (imperial) past, and a spectacle of events and performances.

Of central importance to Tideway's rhetoric is the recurrent idea of reconnection. Tideway's tagline is "Reconnecting London with the River Thames." This implies a former connection. Londoners, it is assumed here, are alienated from the river that forms a major part of their environment. The use in Tideway's colour design of soft greens and browns further enhances a sense of ecological reconnection; implying an alienation from a natural world under modernity that it is necessary for us to reverse.

The future that is being imagined is one of reconnection by Londoners with a clean river that can be the centre of sport, leisure, and also commerce. Tideway has, in a way that shows how big infrastructure projects can exert pressure back on governing and bureaucratic seats of power, taken an important role in encouraging the development of the Port of London Authority (PLA ${ }^{5}$ )'s "Thames 2035 Vision"; a document that describes the re-invigoration of the River Thames in the following categories: "Port of London - More trade, more jobs; Inland freight - More goods off roads onto the river; Passenger transport - More journeys; Sport and recreation - More participants; Environment and heritage - Improved tidal Thames environment; Community and culture - More people enjoying the Thames and its banks" (Port of London Authority, 2015).

\footnotetext{
${ }^{5}$ The authority that governs the river Thames through the heart of the city of London as far as its tidal limits. 7 of 22
} 
David Walters made it very clear that Tideway was an important partner in the development of the Thames 2035 Vision, explaining that he had been "disappointed" in his earliest interactions with the PLA as they:

"had no vision for the river. This was a real problem for us (...) We wanted to rekindle a lost love affair with the river. This meant that we had to have a vision that people wanted to support and care for. (...) So we started to write our own and gave the PLA our vision. For the river to be of maximum use to society it needed to be loved and worked." (Bear, L. 2019. p. 16)

David's phrase "loved and worked" is instructive. The blending of the idea of more freight and commercial traffic with more leisure users and a cleaner and more ecologically sound environment is repeated throughout Tideway's publicity material, without any sense that these ideals may be in conflict or perhaps mutually incompatible. Such rhetoric conjures a sense of an emergent endless bounty; the revival of the Thames will be the rising tide that, proverbially, lift all boats.

Tideway does not see this commercial vision as empty rhetoric. They have committed to moving parts and materials from their sites by river, where possible boasting of having moved " 2 million tonnes by river" since the project's inception (Dobson, 2020) and having massively increased the amount of commercial traffic on the river in recent years (Cadman, 2015). In order to do so, and in another act of engaging together with other important river stakeholders, Tideway "established the Thames Skills Academy (TSA) to meet the needs of employers on the River Thames," (Thames Skills Academy, 2018) something that David described as creating another "legacy" in "rekindling the traditional skill base on the river."

\section{Bazalgette}

Tideway's setting up of the Thames Skills Academy and its harking back to the idea of traditional skills is one of the many examples of how Tideway does not just look forward to a utopian vision of the future of the river, but also how it points backwards into a (similarly mythical, constructed) past. To further unpack this idea of "reconnection," it is necessary to ask what and when was the original "connection" that has now passed?

Tideway's model for a glorious past is easily located in time. The Thames Tideway Tunnel is being built by Bazalgette Tunnel Ltd. and is comprised of a consortium of companies also bearing the name Bazalgette (Thames Tideway Tunnel, 2020:124). The reference is to the British Victorian engineer Sir Joseph Bazalgette (1819-1891) who built the majority of London's still existing sewer network. Bazalgette is famously the man whose infrastructure interventions cleaned up the "great stink" of 1858 when the Thames' corruption with sewage caused an outbreak of disease and an unbearable smell (Halliday, 2013).

The connection between Bazalgette's actions and Tideway therefore is a neat one for Tideway's officials to make. Bazalgette was the last person to clear up the river and the rhetorical link between the current conditions of the Thames and "the great stink" can only make the justification for an intervention like Tideway seen stronger. However, Bazalgette was not merely a civil engineer, he was a Victorian engineer whose transformation of London coincided with London's physical and commercial expansion and its position at the centre of the British Empire at its world-dominating height.

If it were possible to separate Bazalgette as a figure fighting for infrastructure as a solution against disease from his role in crafting London as an imperial capital city, this is clearly not the goal of Tideway. This can be seen through the ways in environmental benefits are linked throughout their 
vision with a rhetoric of commercial success and expansion. Bazalgette, here, represents civil engineering of an explicitly Victorian scale and ambition. It is linked to a transformative ambition that does not just rest at the city's edge, but also sets out to transform the world.

Victorian London, the "then" that was when the river was last a great commercial centre before the Port of London moved to Tilbury in the Thames estuary and then declined in importance (Bear, 2019:13), was a time of growth, expansion, and power. In using this rhetoric, one must forget the dark sides of commerce on the river and of London's imperial wealth. London's Victorian dominance and its infrastructural expansion was built on its wealth as a port city at the centre of a global network of "trade." Gapud (2020) writes, in the context of Bristol, of the condition of aphasia in people's memories and evocations of the past that causes "trade" to be divested of its links to slavery and slave-produced goods. Trade is taken to be a neutral good, bracketed as separate from slavery and the plantation system on which Britain's imperial wealth was built. Even outside of trade from directly slave owned locales in the Caribbean, London's wealth, especially in the later Victorian age, was built on unequal and exploitative trades and seizures of goods from Britain's other colonial dominions

This context of London's commercial success as a port city and the reasons for its expansion is entirely silent in Tideway's images of success: the "then" that is harked back to in Tideway's quest for re-connection is left vague. This is an aphasia of memory, as commercial success is taken as a selfevident good, and where "golden ages" of financial dominance are not critically unpacked. Such an approach resonates strongly with the way in which many British people think about "the Empire" in a positive way as a bringer of more goods than ills (see Gapud, 2020:2) - a pervasive issue that has been seen as a partial explanation for Britain's 2016 vote to leave the EU [Brexit] (Hart, 2016) and or a rise in nationalistic sentiment and rhetoric.

Tideway is not drawing an accurate picture of Bazalgette or the river's commercial past and is seeking to evoke Victorian engineering while deflecting from its core role in Empire. They are, through their rather more casual use of Bazalgette and a gentle nostalgia for the river as a commercial entity, discouraging a close look at or critical engagement with the rhetoric. Bazalgette is here to represent a Victorian approach to engineering. Victorian engineering in this sense means ambitious vision, major projects, the kind of infrastructure that "intoxicates" those who come into its orbit (see Page XX). It represents great over-engineered interventions into cities, whether they are needed on such a scale or not (Page XX). Indeed Bazalgette is known as the great "over-engineer": a man whose sewers were built to serve a city of 4 million people (Halliday, 2013) and which remain the main backbone of a city with twice that population; a man who built his sewers to be beautiful as well as functional, creating the ornate Crossness Pumping Station, known colloquially as the "cathedral of sewage" (ibid.).

\section{The Spectacle}

Bear (2019: 16) notes the extent of this rhetorical link between Tideway and an idealised past of brave engineering and national confidence and recognises its imperialistic content:

"The offices of Thames Tideway publicise its ...deep patriotic connections to Victorian achievements. Visitors can watch livestreams from the construction sites along the river on multiple screens while sitting on fake upturned crates. These are named after the lost wharves of the Pool of London. David explained this was all part of reconnecting the public to their river and showing them the scale of TT's ambition and care."

Tideway's offices are an extraordinary invocation of the imagined future that the sewer represents, and of a similarly imagined past. Along with the names of the lost wharves of London on the crate 
seating, deckchairs in the astroturfed "breakout area" were decorated with the names of Tideway employees that had been transformed into fake company names that could have referred to a goods carrying company from the Thames' commercial heyday (for, e.g., A stamp for "Jones' Finest Fruit and Vegetables" with the Jones in question being Tideway's current Marketing Officer). The heritage here is both imagined and blended seamlessly into the present. The Tideway offices are strategically located on the South side of the river Thames, just below London Bridge so that large glass windows can look out on the river and the City. From this position directly South of the City of London, one is afforded a magnificent view over this centre of financial and societal power.

Between the futuristic-feeling big screens showing promotional material, the ping-pong tables giving the sense of the "cool" campus office, and the deckchairs and astroturf, there is a particular and deliberate impression being created. This is a blending of a fun, almost whimsical, sense of leisure, combining with a sense of heritage (the lost wharves) and ecological care (the recovered driftwood), all in the service of the serious and elemental river and city that dominate the eye from the moment you exit the elevators and are met by the iconic London riverscape and skyline. The meeting rooms are named after the "lost" rivers of London, many of which were culverted into Bazalgette's original sewers. In this way and throughout Tideway's description of their overall motivating vision, "lost heritage" is rhetorically brought back into the light and re-engaged with: nothing that may be rhetorically useful is left below the surface.

Outside of the office, Tideway has, systematically and showing a great flair for publicity, become involved in or initiated events on the river that will spread their vision outwards for the benefit of various publics. They have become heavily involved in and financed the Thames Festival, an annual artistic festival of events on the river. There is also the aforementioned engagement with Thames 21, a charity, previously critical of Tideway, brought into their orbit through concerted and deliberate engagement, gifting, and charismatic partnership building. Tideway created sporting events on the river, including regattas and, when Professor Bear and I visited, they had plans in operation to host football matches on pontoons floated in the river.

Their construction of the sewer was mythologised to the point where it was turned into a television show "The Five Billion Pound Super Sewer" (see BBC, 2019), which blends footage following a number of Tideway construction workers with an investigation of the Victorian sewer network sewers, explored and introduced by the Thames Water workers who patrol its lengths to clear obstructions.

The idea that mega-projects or the intervention of any large economic change needs a vision and a spectacle in its service has been explored by Evans (2017: 132):

Tsing (2005)... shows how attracting global capital flows to new sites of development requires both a spectacular drama, a fantastical 'economy of appearances', and cultivation of the false idea that the new frontiers of capital expansion, in any time and place, are formed by the heroic conquering of wild places and wastelands devoid of human history. Psychogeographer Iain Sinclair (2012) describes as 'ghost milk' the urban planners' fantastical imaginations of a post- Olympic Games future in the East End of London, visions of an imagined time and place that... similarly rely on the notion of a wasteland and bear no relation to, and have no respect for, the historical significance of what has been displaced.

Tideway's "fantastical visions" also depend upon the rhetorical creation of a future of prosperity and a present that is a kind of wasteland (in the form, here of the polluted river, imagined as neglected, unused, and alienated from the city). However, as I have described for Tideway, there is also a past invoked and made safe by these visions. This is not quite the "spectacle" as Baudrillard (1994) would understand it; it can certainly be hyper-real and is designed to stimulate senses, emotions and desire, 
but it is fuller of real symbolic content than Baudrillard recognises (ibid). In a Baudrillardian sense, however, these spectacles tend to create "simulacra"; visions of a future of revelatory perfection far beyond the actual possibilities of the act or event and filled with a rather vague or even utopian set of ideals and hard-to-measure ends. For a successful intervention like an infrastructure mega-project, a global mega-event like the Olympics, or the Indonesian logging interventions that Tsing (2005) describes to be effective; constructs of the past, present and future must be knitted together and brought into a collapsed temporal moment in the service of a particular transformative vision, a vision that is only ever a simulacrum of the true transformation at hand.

Thus, it has been shown that for all of the promised transformational effects of infrastructure, there is, inevitably, a rather different economic and political reality to these projects that exists behind these spectacular visions that are so carefully marketed and sold to publics ${ }^{6}$. I explore Tideway's somewhat occluded other face in the next section, demonstrating how the "desires" of finance shaped Tideway as an intervention. This next section is at the heart of its interdisciplinary approach. We contend that anthropologists are used to describing the visions and spectacular imaginaries of large infrastructure projects, but are generally, and with notable exceptions, less used to focusing on such projects as financial impositions. I argue that turning a focus to the financial vehicle that is built to deliver the project offers us a vital tool of analysis; one that does much to explain the infrastructure's coming into being in a far more concrete manner than a focus on the rhetorical play and manipulations that make up infrastructure's public-facing "glinting surfaces."

\section{Section 3. Why does Thames Tideway Exist? The financing story}

\section{The Desires of Investors}

The Thames Tideway Tunnel is both a mega-sewer and at the same time the "solution" to a very specific series of "problems" faced by the international investment community. The financial realities and relationships that are hidden by Tideway's image are far less utopian, correspond to specific underlying material conditions in particular with regard to finance, and have serious implications for consumers and taxpayers. Beneath the glitzy veneer, Thames Tideway is a "Special Purpose Vehicle" (a company set up by a consortium of investors for the sole purpose of holding a specific asset) outside of Thames Water, which will regain ownership of the asset when construction is complete in 2024 and whose customers' water bills are already funding it (Loftus and March, 2017). It is privately financed and owned through the Regulated Asset Base (RAB) system which is mainly used for water and energy networks in the UK and assures investors of their returns on the asset base through a system of periodic price controls. These make returns highly secure. ${ }^{7}$ The government's involvement is through a regulator with some limited legal powers, which in the case of Tideway is Ofwat. Particular features that are unusual about Tideway compared to other major infrastructure projects deploying RAB are that investors can draw a profit from it before it is completed (ibid: 12) and that the UK Government is acting as an "insurer of last resort" in the case of overspends on the project, meaning that the UK taxpayer would bail out Tideway if necessary (Tideway, 2016). In this way, Tideway has

\footnotetext{
${ }^{6}$ However, it is important to note that a closer attention to the actual decision-making processes in operation within an infrastructure project than was possible here for reasons of access would do even more useful analytical work. For example, a focus on the ideologies, schemas and cultures of marketing professionals working in the infrastructure sector would add even more detail and depth to an analysis such as this, in the same way as Kalman Applbaum's ethnography of American Transnational Consumer Marketing (Applbaum, 2000) helps us to better understand the actions of both companies and consumers. An ethnography of an infrastructure projects marketing, communications and PR strategies from an embedded position within the project would be welcome to provide even more rich and nuanced understandings of the emergent infrastructure assemblage.

${ }^{7} \mathrm{RAB}$ refers to any assets that are privately financed, funded through user bills, and privately owned. The government's involvement is through a regulator with some limited legal powers.
}

11 of 22 
come into being as a fundamentally experimental intervention, helping to reformulate the rules and norms around infrastructure as it has been designed and implemented. This aligns with Casper Bruun Jensen and Atsuro Morita's understanding of infrastructures as ontological experiments that are full of the power to speculate, transform, and change the world around them (Jensen and Morita, 2017). The emergent distributional effects of this model of financing are discussed further below (see pages $\mathrm{XX}-\mathrm{XX})$.

Tideway presents an infrastructure financing model that has emerged in the midst of attempts to reconfigure the UK's infrastructure financing landscape. The latter has been in a state of flux since the abolition of the Private Finance Initiative (PFI and PF2) in 2018 (HM Treasury, 2018). An important feature of the attempted redesign is to mobilise institutional investors as new sources of infrastructure finance. Institutional investors, including pension funds and insurers are increasingly seen as being the answer of the problem of how to bridge the "investment gap" in infrastructure (see Della Croce, 2011). The "investment gap" is seen by the UK Government as a national problem (Varma, 2018) and private finance is emphasised as a solution (HM Treasury, 2019). Institutional investment such as from pension funds and insurers is seen as a major and largely untapped resource, representing a ready flow of financing. This has a set of implications.

First, the investment of pension funds in infrastructure has the ability to make workers, through their pension contributions, part of the private financing of infrastructure, and, in turn, for them to be invested in the infrastructure that they use. When people's futures are part of a private asset, they are less likely to support its return to public ownership, as has been seen in the decline in support for the nationalisation of Britain's water supply when the public were made aware of the deep involvement of pension funds in the sector (Water UK, 2019). In this way, rather than people feeling disenfranchised from their infrastructure, they are bought in, although not in the same way that they would be if the infrastructure were publicly owned. Part of the success of the Thatcherite privatisations was the reframing of the public good that made customers shareholders in the previously nationalised industries (Bayliss, 2014). This redefined the notion of the public good as a set of new moral relationships between consumers, shareholders, and companies, rather than as a set of rights and responsibilities between citizens and the state (Bear and Mathur, 2015).

Second, what kind of projects are attractive to institutional investors? Pension funds and insurers have a preference for long term stable returns and for investments that are low risk to fill a gap in their portfolios (Caballero et al., 2017). In politically volatile times, infrastructure and utilities present a stable and low risk return that can be more attractive than investing in government bonds that currently have all-time low returns due to interest rates and that, therefore, leave a particular low risk shaped gap in investor's portfolios. Ideally, from the investors' point of view, the relationship between infrastructure provider and consumer will avoid the government entirely and the long term return can be provided directly by a captive customer. One investor from an organisation that advocates for the investment community indicated that having direct access to customer bills was, a good thing for private finance as "the government is a poor assessor of value [for money], unlike consumers"; conveniently forgetting how many utilities are full or partial monopolies, giving consumers no choice whatsoever or opportunity to assess value for money. The institutional investors that are sought as a solution to the "infrastructure gap" are, therefore, looking for projects that allow them direct and stable returns from a customer base through tariffs. They will ideally achieve these returns not through a direct provisioning through the State that may get in the way or prove inefficient, but rather distanced by soft-touch regulation. These preferences can be seen through the popularity of the Regulated Asset Base (RAB) model, which offers secure returns to investors and incentivises their investments. RAB is a model that many interviewees from the investment community have spoken about as being a form of private investment structure that "works" for them and has not been "tainted" by the failures of the PFI and PF2 financing initiatives that were based on contracts between projects and the government. 
Third, RAB may work for investors, but this is not necessarily the case for consumers. "The ... RAB model for water and energy networks" ensures "investors of their returns on the asset base through a system of periodic price controls, which means that returns are highly secure" (Bayliss et al. 2019). However, "the evidence from the application of the RAB model in water and energy in Britain indicates that it comes at considerable cost to consumers" (ibid.). Further, "for companies regulated by the RAB model, attention to VFM [value for money] appears to be much weaker" (ibid.) than the measures demanded by the UK Treasury [HMT] and National Audit Office. The accusation of failures of value for money that has been levelled at PFI and PF2 (Whitfield, 2020) can be seen to apply to regulated utilities under the RAB model also, whatever the rhetoric of investors may be.

These specific configurations of infrastructure financing are set up to face a hungry demand from global finance, and this entire understanding is based on an idea of risk that privileges the private sector and sees any "interference" or mitigation from the public sector as undesirable and as a factor that will only make infrastructure more expensive through discouraging investment. This, of course, affects what is built in the environment. Specifically, as the next section shows, the interests of pension funds and other institutional investors leads to infrastructure projects of a grand scale.

\section{Scale}

The current set of needs and desires of investors privileges a specific scale of infrastructure project. Big infrastructure projects can guarantee a "buzz" of private finance, similar to the ways that the large privatisations of utilities and infrastructures created rushes to invest in the 1980s and 90s. If the project is linked to long term stable returns and the risk profile is low, then pension funds will be interested. Big infrastructure projects can also be "too big to fail" (to steal a famous phrase) as too much is invested by too many parties, including political careers and reputations. An illustration of how scale prevents failure is provided by the government's role as an insurer of last resort for Tideway. Interviewees spoke about how projects of "a certain scale" will not be "allowed to fail" by a government that fears spectacular and visible project collapse. Interviewees spoke about how big projects can become both "magnets" for investors, but also have a "momentum" of their own when they are in progress, making their completion inevitable once enough time, money and other resources have been invested. Scale of infrastructure, thus, makes a project of a certain scale less risky as it cannot be allowed to go wrong. This is not the only reason, however, why big mega-infrastructure is preferred over smaller and more everyday alternatives for provision.

First, it was a repeated concern of many of our participants who are engineers that projects tend to be preferred where a government minister or other government decision-maker can add to their legacy through demonstrating the power to create large and visible interventions into the landscape. One high-level civil engineer said that "politicians will fund anything that gives them a big ribbon to cut [in inaugurating a project] and that makes them look good." One engineer with whom we spoke bemoaned how maintaining existing systems is just "not as sexy" and how money tends to be made more readily available for "building big new shiny things." In the background here is the context that big infrastructure - large pipes, big roads, tall towers - have become part of our cities for reasons which demonstrate that cities have traditionally been designed by male architects and engineers (Kern, 2020). Architecture is frequently phallic or otherwise represents the imposition of the 'manmade' on the 'natural' in overt and unsubtle ways. Tideway is, itself, a particularly symbolically rich utilisation of massive drills, gigantic pumps and earth drilling machines of enormous girth, whilst also providing a large and spectacular set of obvious transformations on which politicians can cut a series of suitably large ribbons. 
This is of particular concern in the context of Tideway when there have been significant critiques of its necessity in its existing form, and where there has been the repeated suggestion that smaller interventions could have answered the same problem that Tideway's massive tunnel does, only less expensively (Binnie, 2014; Griffiths, 2014; Jacobs Babtie, 2006). In an interview with a Tideway media advisor, I suggested that not everyone approved of Tideway as a project. The Executive himself articulated one of the most important counter-arguments to Tideway when he answered "Yes, you must be referring to the SuDs debate?" He went on to explain that "many people think that Sustainable urban Drainage Systems [SuDS] is the way around the problem of sewage in the river." SuDS is an approach to drainage that "mimic[s] nature and typically manage[s] rainfall close to where it falls" (susdrain.org, n.d). It is a system of small, natural processes mimicking and enhancing natural drainage that reduces the need for more traditional sewers and overflows and can be retrofitted through cities for a lower cost than something like Tideway. The Tideway executive, after suggesting SuDS to me, suggested that both an intervention like Tideway and SuDS should be used together and blended, and pointed out that Tideway had funded a research position on SuDS at the London Mayor's Office: one research position looking into SuDS balanced against Tideway’s $£ 4$.2bn price tag in an act of apparent tokenism. ${ }^{8}$

Second, there is the intoxication and symbolic power of the large, bold intervention for all those involved. To illustrate this sense, the Chair of the Public Accounts Committee of the House of Commons, Margaret Hodge called the project a "big vanity infrastructure project" (Loftus and March, 2017: 6) whilst a Department for Environment, Food and Rural Affairs (DEFRA) civil servant at a meeting I attended more positively stated that, over the course of her involvement with the project she had, while originally a sceptic, become "intoxicated by the power of big infrastructure." Her involvement in the project had given her a sense of the power of making major interventions into the landscape. Further, I have already described how, by choosing Bazalgette as a rhetorical model and making frequent connections back to how the project is infrastructure on a scale that "we don't as a country do any more" (as a senior executive of Tideway said in an interview) and of the project as engineering on a Victorian scale, there is a clear discursive link being made to an (unrealistic) nostalgic golden era. This chimes with Loftus and March's (2017) description of Tideway as "a Victorian solution to a 21 st century problem or 'an outdated and expensive folly' as the Thames Blue Green Economy Group refers to it (Ashley, 2014; TBGE, 2016; Water Briefing, 2016)" (2017). Tideway could be seen as an "unsolicited proposal" as characterised by Shaoul (2011): an intervention that is not solicited by a government, but comes to them due to the actions of other powerful forces.

Big infrastructure works for investors, for politicians, and also for the legacies of many of those involved in its building. It is just unclear, as we will see in the next section, whether it works for those communities that it is intended to serve.

\section{Who benefits?}

This section turns to political economy to illuminate the distributional impacts of the particular financial forms of Tideway, which easily remain hidden beneath Tideway's glitzy presentation (see above). The political economy of financialisation helps us to track Tideway's effects. Financialisation is a way of describing the increasing importance and complexity of speculative capital in a part of the economy (here infrastructure); thus where "power in the economy has shifted to some degree from the production of value to the extraction of rents" (Loftus and March 2017: 10).

\footnotetext{
${ }^{8}$ Sarah Whatmore's work in Yorkshire (see Whatmore and Landström, 2011) suggests a flip side to the scaling power of finance's visions. In Whatmore's ethnography, a less ambitious and smaller scale infrastructure solution, in her case the initiation of 'competency groups' of GC's to combat flooding was adopted against a major flood defence infrastructure scheme due to the absence of interest from finance. In this case the lack of finance appears to have made space for an inclusive and more effective response.
}

14 of 22 
Loftus and March summarise how financialisation has been achieved in the case of Thames Tideway through a design which allows the revenue streams generated by Tideway to be securitised and sold off as speculative assets in financial markets; feeding the engine of finance and speculation and providing investors with the core assets with which to trade and re-trade. They write how:

\begin{abstract}
"Under conditions of financialisation, we witness not only a changing makeup of investors profiting directly from water infrastructure, we see the emergence of a whole shadow economy that is not subject to the formal regulation of OFWAT. A narrow focus on direct returns to investors tells us far less about the forms of rent extraction now animating investment decisions within the sector, which are more focused on the capture of rents than the profits to be generated from the direct sale of water." (Loftus and March, 2017. p. 13)
\end{abstract}

Tideway, when viewed in this context, then projects not solely a national, but equally appeals to an international vision, offering an investor-oriented instrument in the service of further financialisation of the water sector in the UK (Bayliss, 2017) and of urban city infrastructure, more generally (Pike et al., 2019). This raises a further set of issues.

First, Tideway is ultimately owned by a Special Purpose Vehicle [SPV], a company put together for the specific purpose of the investment, called Bazalgette Equity Ltd. The shareholders of this company are Allianz Infrastructure, private equity fund managers Dalmore Capital, IPP Bazalgette (Investments) Ltd, Bazalgette (Investments) Ltd which has Swiss Life GIO as its parent company, and private equity fund managers DIF, via a company named DIF Bid Co Ltd. It may, therefore, seem to represent some of the infrastructure investment from the institutional investors that the UK is searching for, for as Swiss Life is a pension fund and Allianz an insurer ${ }^{9}$. However, even if they are investing for institutional investors and have similar names, these companies themselves are not pension funds or insurers, but rather are specially created investment vehicles. Allianz Infrastructure is registered in Luxembourg. The parent company of IPP Bazalgette is International Public Partnerships Ltd, a company registered in Guernsey. Swiss Life GIO is a company incorporated in Luxembourg. ${ }^{10}$ Therefore, all of the companies with a share in Tideway are either private equity funds (representing wealthy investors' interests) or are registered in tax havens. Investors profit not just from dividend payments but also from interest paid on loans to Tideway from shareholders. These investor companies may be investing on behalf of pension funds and insurers, but they will be also managing the funds of wealthy individuals and companies, and are managed by investment fund managers who extract a hefty fee. Their offshore registration makes it difficult to trace exactly where the money goes once it is passed to these investors.

Second, these financiers have, unusually, been able to receive money from Thames Water customers' bills before the project is complete. Thames Water customers, who represent $20 \%$ of the UK's customer base, will all receive an average increase of $£ 20-25$ on their annual water bills (Water Briefing, 2019). This is the case whether or not they will benefit from Tideway, and many of Thames Water's customers do not live in London. Customers will be paying for the Tunnel multiple times over as the investors take their returns from customer tariffs for many years to come (Loftus and March, 2017:11). These payments are predominantly being extracted offshore in ways that are hard to follow and map.

Third, by building a SPV for the project outside of Thames Water, a water company that has previously been aggressively financialized, there are no risks to the highly leveraged Thames Water if the

\footnotetext{
${ }^{9}$ Albeit large European institutional investors, against the nationalistic and parochial image of Tideway.

${ }^{10}$ Information on the ownership of these investors in Tideway was taken from the Financial Statements of the companies that Tideway lists as its investors in its Annual Report (Tideway, 2020).

15 of 22
} 
project were to fail (Loftus and March, 2017: 10). Indeed, the reason why Thames Water has not built the sewer itself but has appointed an external infrastructure provider, is that it has become highly leveraged due to the extractive financialising practices of its investors, such as the Australian investor Macquarie. By 2010, it was clear that Thames Water could not pay for the sewer itself and an external infrastructure provider would be sought due to its own financial history. As the National Audit Office summarised, Thames Water could not afford to construct the sewer due to the company's "recent strategy to increase its borrowing and pay substantial dividends to its owners" (NAO, 2014: 25). Thames Water, not able to further open itself up for financialisation, opened up another avenue: "thus, the hydrosocial cycle had been part financialised by Thames, this process was closed by the entry of Bazalgette Tunnel Ltd" (Loftus and March, 2017: 12). Therefore, the cost of Tideway, and the risk if it fails, is not carried by Thames Water or Tideway's owners or executives. Rather, it is offloaded onto the customers who will fund the project, and taxpayers who would be required to pay if the UK Government has to step in and make good its promise to be the project's "insurer of last resort." While Thames Water was deemed unable to finance the sewer from its own accounts, in the long run it will still be financed from the bills of their customers.

Tideway is, then, in many ways a successful case in terms of the narrow framing of infrastructure projects set by the Treasury: to attract private investment in order to bridge the "infrastructure gap." This apparent success raises a number of issues regarding the equitable nature of infrastructure and service provision. It is broadly on budget and on time and the amount that it will cost customers tends to be forecasted down rather than up. It has recorded an impressively low cost of capital (CEPA, 2015). This means that its particular organisational form (a large RAB financed project external to a particular existing provider) is likely to be an experiment that may be repeated with other large infrastructure projects, perhaps even with the UK's next generation of nuclear power stations (Thomas et al., 2019). This said, there are clear dangers of taking Tideway as a model for the future of infrastructure financing as it opens a channel for predatory investors. Indeed, as Bayliss et al. (2019) summarised in response to the UK Government's consultation on infrastructure financing, this model for financing holds many of the dangers that led to the spectacular failures of PFI: "the RAB model, with bills inflated by interest, dividends and remuneration of directors, would appear to be equally as poor value for money as PFI has been for tax-payers. As with PFI, lower cost public investment options risk being ignored". RAB is not a model with lower risks or costs to the public. It is a model with lower risks and costs to investors and presents an opportune vehicle for financialisation and rent extraction in infrastructure.

\section{Section 4. Concluding: A new conception of the public good?}

This paper demonstrates how an interdisciplinary approach across anthropology and political economy can illuminate infrastructure projects from multiple directions. Future analysis should emphasise that different constituencies in the world of infrastructure financing are trying to transform the infrastructure to suit their particular needs and perspectives. Namely, governments may want to attract private investment and to limit public expenditure on their balance sheets; financiers usually want the most profitable and risk-free possible returns and often have a particular gap in their portfolios that can be filled by infrastructure; and engineers often desire a more "rational" and less "politicised" set of decisions on infrastructure. End users and tax payers, by contrast, have little control over their infrastructure. These powerful decision makers share a set of assumptions: that the private sector is more efficient and has more information than the public sector; that taking on more risk means that more reward should be expected; that government intervention is a kind of risk broadly to be avoided; that the government's role is to support the private sector; and that the eventual funders (tax and bill payers) are a revenue stream to be tapped into rather than the constituency to be protected. 
Political economists can describe the distributional outcomes of this reality in ways that some anthropologists may be unfamiliar with. However, anthropologists are able to look at the social and ideological way in which these discrete constituencies construct a vision of the world, through careful attention to their ethnographic realities. These elite actors and their social formations and systems of organisation are important if we want to understand how our built environments come to look as they do, but anthropology can miss them, in a focus on the effects of power rather than its causes, in a way that can leave gaps in our understanding. Anthropology's "trouble with elites" has long been recognised (see Nader 1972; Lotter 2004) and ignoring elites can leave gaps whereby powerful actors are shady presences on the edges of ethnographic tales, or caricatured antagonists, appearing in writing as they appear to the participants in ethnographies, but as such devoid of agency. Looking at how powerful actors shape the worlds of the less powerful can be a productive analytical tool for illuminating social realities.

Anthropology can also add a focus on the way in which an infrastructure project is created and curated as a construct. It is an assemblage of ideas, symbols and images, designed to face a series of different publics; a classic kind of ethnographic object. This is not to say that an infrastructure project has a "back stage" for political economists to attend to and a "front stage" for anthropologists to unpack, as a proper excavation of these spaces shows that both the public and the private representations created around infrastructure projects are constructs put together for audiences. The infrastructure project itself is a Janus-facing assemblage of actors, technologies, ideas, and material and financial flows. Interdisciplinarity, here, is not a utopian ideal or a buzzword, it is a necessity emerging from the complexity of the object. For instance, if we are to understand what motivates the strategies of charismatic leaders in the creation of speculative infrastructure projects, we must understand the drivers behind these projects, the constituencies that they are ultimately designed to serve, and the effects (material, social and financial) that their designers intend to produce. Otherwise, charismatic infrastructure leaders' practical polyvocality - their ability to create visions of the world that appear as convincing to private equity funds as they do to Civil Servants, or to rowing clubs, or skeptical water bill-payers - will not be fully appreciated. These are actors whose skills at consensus building, envisioning futures, and assembling unlikely alliances can only be understood if our approaches engage in similarly inventive and adventurous skill sharing ourselves.

What has been demonstrated here is how a broadly economic and ideological set of shared ideas create particular forms of infrastructure. In Thames Tideway Tunnel, we find a particular exemplar of a de-risked, massive, government-backed, SPV-owned piece of infrastructure that may well represent the "mega-projects" of the future and come to dominate our built environments. These infrastructural mega-projects, just like mega-events (Evans, 2016), are financial occurrences as much as they are technological, social, or sporting. They connect into global financial extractive flows that give elite actors such as private equity funds and investment managers access to our utility bills, our tax revues, or directly to our wallets through user charges. Increasingly their rent extracting financial logics are what dictates the shape of the housing, utilities, sporting events, and supply chains that make up most of our lives. They do so clothed in imaginary and spectacle that an anthropologist is particularly well placed to critically unpack.

Finally, this has implications for the public good. What we see in the case of Tideway is that something that was once, in the UK, at least for a time, considered an inalienable public good - water and sanitation provision and the environmental protection of the river - is now framed as an opportunity for investment and for profit. Privatisation, of course, began this process, but the recasting of environmental concerns not as legal and moral matters, but rather as threats, opportunities and commercial concerns represents a new conception of the public good as a set of commercial moral relationships. Here we are not citizens but consumers, with rights and responsibilities negotiated between us and commercial actors, rather than between us and states. Here the state is present only to enable a "fair" balance between the interests of consumers and capital. This is not to imply a (morally loaded) 
improvement or degeneration of a relationship over time; water has always moved in and out of different modes of provision and ownership in the UK and elsewhere. It is, however, a transformation, whereby the question of how should water and its necessary infrastructure be provided (and here we are implying a contract of rights and responsibilities, a debate around the relative morality of public and private provision) is less of interest than the question of how market mechanisms can be served in the answering of a particular material puzzle. Similarly, this is not disenfranchisement or alienation; a new public good is made where we are involved, but it is a new public good co-constituted from the outset as capitalist and concerned with consumption (Bear and Mathur, 2015). Here we are dragged back into a morally loaded relationship with water supply and the river that we have not had since water was a public good in the older sense. Even as our pensions (symbolically, our futures) are increasingly made part of private financing, we are implicated again as actors engaged in service provision. But here, we are not recipients of public goods that we can claim as our due (not to imply that this was ever a long-term or stable norm), but more complexly we are simultaneously interpellated as consumers and providers, as exploiters and as the exploited, as inseparable from the capitalist edifice and unable to see or act externally to it.

This is a new public good outside of public provision, with its own emergent moralities, rights and responsibilities. In this way, there is a significant redistribution of power in action, as what is desirable, moral and right comes to be counted as that which is desirable, moral and right for investors and for an abstract notion of the national economy, in which communities and individuals are involved, but their desires and perspectives are subordinated in the service of the apparently de facto goods of growth, profitability and the reduction of investment risk. This new emergent public good is so complicated an object that it is, in our understanding, one of Barthes' "objects belonging to no one." These are objects that imply an interdisciplinary approach that can use varied perspectives to excavate new entanglements between actors and institutions both with-in and with-out the State. It is this new public good that we must attempt to map if we hope to understand both the emerging infrastructure landscape, and more widely the emerging realities of contemporary capitalism, its power to create material effects, and the manner in which we come to be governed.

\section{References}

Aneesh, A. 2009. Global Labor: Algocratic Modes of Organization. Sociological Theory. 27 (4): 347-370

Appel, H. 2017. Towards an Anthropology of the National Economy. Cultural Anthropology. 32 (2): 294-322

Appel, H., N. Anand and A. Gupta. 2018. "Introduction: Temporality, Politics and the Promise of Infrastructure" Ch 1, pp. 1- 38 in N. Anand, A. Gupta and H. Appel (Eds.) The Promise of Infrastructure ,Duke University Press: Durham and London

Applbaum, K. 2000. Crossing Borders: Globalization as Myth and Charter in American Transnational Consumer Marketing. American Ethnologist. 27(2): 257-282

Ashley, R.M. 2014. It was good enough for the Victorians: We know it works. [Online]. Available at: http://cleanthames.org/the-controversy/ experts-opinion/. Accessed: 28/07/2020

Baudrillard, J. 1994. Simulacra and Simulation. Translated by Sheila Faria Glaser. Ann Arbor, MI: University of Michigan Press

Bayliss, K. 2014. Case Study: The Financialisation of Water in England and Wales. FESSUD.

Working Paper 52. Available from: http://fessud.eu/wp-content/uploads/2015/03/Case-study-the- 
financialisation-of-Water-in-England-and-Wales-Bayliss-working-paper-REVISED_annexes-working-paper-52.pdf

Bayliss, K. 2017. Material cultures of water financialisation in England and Wales. New Political Economy. 22 (4): 383-397

Bayliss, K., Bowles, B., Van Weayenberge, E. 2019. Response to Infrastructure Finance Review Consultation. [Document submitted to HM Treasury Infrastructure Finance Review Consultation]. Unpublished

Bear, L. 2007. Lines of the Nation: Indian Railway Workers, Bureaucracy, and the Intimate Historical Self. New York: Columbia University Press

- 2015. Navigating Austerity: Currents of Debt Along a South Asian River. Stanford, CA: Stanford University Press

- Bear, L. 2019. Fixing Inequalities in Time: Radicalising Westermarck's Moral Emotions for a Critique of Financialised Speculation. Edward Westermarck Memorial Lecture, August 2019. Suomen Antropologi. 44 (3-4): 3-23

Bear, L and Mathur, N. 2015. Introduction: Remaking the Public Good: A New Anthropology of Bureaucracy. The Cambridge Journal of Anthropology. 33 (1): 18-34

Bear, L; Ho, K; Tsing, AL.; Yanagisako, S. 2015. Gens: A Feminist Manifesto for the Study of Capitalism. Cultural Anthropology. https://culanth.org/fieldsights/gens-a-feminist-manifesto-forthe-study-of-capitalism

Binnie, C. 2014. Thames Tideway Tunnel: Costs and benefits analysis. [Online] Available at: $\mathrm{http}: / /$ bluegreenuk.com/references/government_institutional/A6.\%20Binnie \%20-\%20Cost\%20Benefit $\% 20$ Analysis $\% 20$ and $\% 20$ in-river $\% 20$ scheme $\% 20$ Version $\% 2011$ th $\% 20$ Feb $\% 202014 \% 20$ Revision\%204.pdf. Accessed: 23/07/2020

Cabellero, R. J., Farhi, E., Gourinchas, P. 2017. The Safe Assets Shortage Conundrum. Journal of Economic Perspectives. 31 (3): 29-46

Cadman, E. 'Thames feels the strain with traffic set on course to treble by 2019.' Financial Times. September 27th 2015. Available at: https://www.ft.com/content/b79cd312-62b8-11e5-a28b50226830d644. Accessed: 23/07/2020

Callon, M. 1987. Society in the making: The study of technology as a tool for sociological analysis. In T. Huges, \& T. Pinch (Eds.), The social construction of technological systems: New directions in the sociology and history of technology (pp. 83-103). London: MIT Press

CEPA, 2015. https://www.cepa.co.uk/images/uploads/documents/CEPA_Thames_Tideway BWACC briefing note final.pdf

Chalfin, B. 2012. Neoliberal Frontiers: An Ethnography of Sovereignty in West Africa. Chicago, Il: University of Chicago Press

Clifford, J. 1986. Partial Truths. In J. Clifford and G. Marcus (Eds.) Writing Culture: The Politics and Poetics of Ethnography. Berkeley, CA: University of California Press 
Dalakoglou, D. 2010. The road: an ethnography of the Albanian-Greek cross-border motorway. American Ethnologist. 37 (1):132-49

Della Croce, R. 2011.“Pension Funds Investment in Infrastructure: Policy Actions”, OECD Working Papers on Finance, Insurance and Private Pensions, No. 13, OECD Publishing. Available at : https://www.oecd.org/daf/fin/private-pensions/49049712.pdf. Accessed: 23/07/2020

Dobson, J. 2020. The social value of infrastructure: Two case studies from the UK. [Online]. Available at: https://www.rics.org/uk/wbef/megatrends/markets-geopolitics/the-social-value-of-infrastructure-two-case-studies-from-the-uk/. Accessed: 23/07/2020

Evans, G. 2016. London's Olympic Legacy: The Inside Track. London : Palgrave Macmilla

- 2017. Minutes, Meetings and 'Modes of Existence': navigating the bureaucratic process of urban planning in East London. Journal of the Royal Anthropological Institute. 23 (1) 124-137

Gapud, A. J. 2020. Displacing empire: Aphasia, 'trade', and histories of empire in an English city. History and Anthropology. DOI: 10.1080/02757206.2020.1726905

Griffiths, I. 2014. Planned London super sewer branded waste of time and taxpayer money. The Guardian. 27 November. Available at: https://www.theguardian.com/environment/ 2014/nov/27/london-super-sewer-branded-waste- time-money. Accessed: 23/07/2020

Halliday, S. 2013. The Great Stink of London: Sir Joseph Bazalgette and the Cleansing of the Victorian Metropolis. Stroud: The History Press.

Hart, K. 2016. Brexit: Where once was an empire. Anthropology Today. 32 (5): 1-2

Harvey, P and Knox, H. 2015. Roads: An Anthropology of Infrastructure and Expertise. London and Ithaca \& London: Cornell University Press

HM Treasury. 2018. Budget 2018. Private Finance Initiative (PFI) and Private Finance Initiative (PF2). [Online]. Available at: https://www.gov.uk/government/publications/private-finance-initiative-pfi-and-private-finance-2-pf2-budget-2018-brief. Accessed: 23/07/2020

HM Treasury. 2019. Infrastructure Finance Review consultation. [Online]. Available at: https://assets.publishing.service.gov.uk/government/uploads/system/uploads/attachment_data/file/785546/infrastructure_finance_review_consultation_web_version.pdf. Accessed: 23/07/20 20

Ho, K. 2009. Liquidated: An Ethnography of Wall Street. Durham, NC: Duke University Press

Jacobs Babtie. 2006. Independent Review to Assess whether there are Economic Partial Solutions to Problems caused by Intermittent Storm Dis-charges to the Thames Tideway-Phase 1 Final Report. Office of the Director General of Water Services, Ofwat Ref: PROC/01/0021.

Jensen, C. B. And Morita, A. 2017. Introduction: Infrastructures as Ontological Experiments. Ethnos. 82 (4): 615-626

Joyce, P. 2003. The Rule of Freedom: Liberalism and the Modern City. London: Verso

Kern, L. 2020. Feminist City: A Field guide. London: Verso 
Larkin, B. 2013. The Politics and Poetics of Infrastructure. Annual Review of Anthropology (42) $327-43$

Li, T. M. 2007. The Will to Improve: Governmentality, Development and the Practice of Politics. Durham, NC.: Duke University Press.

Loftus, A. and March, H. 2017. Integrating what and for whom? Financialisation and the Thames Tideway Tunnel. Urban Studies. DOI: 10.1177/0042098017736713

Lotter, S. 2004. Studying-up those who fell down: elite transformation in Nepal. Anthropology Matters. $6(2): 1-9$

Nader, L. 1972. Up the Anthropologist - Perspectives Gained from Studying Up. In Reinventing Anthropology. D. Hymes (Ed.) New York: Pantheon

National Audit Office (NAO). 2014. Thames Tideway Tunnel: Early review of potential risks to value for money. Available at: https:// nonpolitical/report/thames-tideway-tunnel- early-review-potential-risks-value-money/. Accessed: 23/07/2020.

Ouroussoff, A. 2010. Wall Street at War: The Secret Struggle for the Global Economy. Cambridge: Polity

Pike, A., O'Brien, P., Strickland, T., Thrower, G., Tomaney, J. 2019. Financialising City Statecraft and Infrastructure. Cheltenham: Edward Elgar Publishing

Port of London Authority. 2015. Thames 2035: The Vision for the Tidal Thames. [Online]. Available at: http://www.pla.co.uk/assets/thevisionforthetidalthames.pdf. Accessed: 23/07/2020

Shaoul, J. 2011. 'Sharing 'political authority with finance capital: The case of Britain's Public Private Partnerships. Policy and Society. 30: 209-220

Simpson, E. forthcoming. Highways to the End of the World: Roads, Roadmen and Power in South Asia. London: Hurst

Sinclair, I. 2012. Ghost Milk: Calling Time on the Last Project. London: Penguin

Star, S. L. 1999. The ethnography of infrastructure. American Behavioural Scientist. 43 (3):377-91

susdrain.org. N.d. Sustainable Drainage. [Online] Available at: https://www.susdrain.org/delivering-suds/using-suds/background/sustainable-drainage.html. Accessed: 23/07/2020

Thames Blue Green Economy Group (TBGE). 2016. The Case Against the Thames Tideway Tunnel and in favour of Integrated Water Resource Management for the Thames Tideway. [Online]. Available at: http://bluegreenuk.com/freewater/ tbge/References/The $\% 20$ case $\% 20$ against $\% 20$ the\%20Thames\%20Tideway\%20Tunnel.pdf. Accessed: 27/07/2020

Thames Skills Academy. 2018. AN INTRODUCTION TO THE THAMES SKILLS ACADEMY. [Online]. Available at: https://www.thamesacademy.london/about-us/. Accessed: 23/07/2020

The Five Billion Pound Super Sewer. 2019. BBC2/Raw. Broadcast 27th January - 10th February. 
The Roads Project. N.d. THE ROADS PROJECT: An ethnographic project on roads and the politics of thought in South Asia. https://www.roadsproject.net. Accessed: 07/07/2020

Thomas, S., Bradford, P.,Burke, T., Dorfman, P. The Proposed RAB Financing Method. Nuclear Consult. [Online]. Available at: https://www.nuclearconsult.com/wp/wp-content/uploads/2019/10/NCG_RAB_submission.pdf. Accessed: 27/07/2020

Tideway. 2016. Bond Investor Presentation. [Online]. Available at: https://www.tideway.london/media/1579/bond-investor-presentation-may-2016.pdf. Accessed: 27/07/2020

Tideway. 2020. Tideway Annual Report 2019/20. [Online]. Available at: https://www.tideway.london/media/4491/tideway-annual-report-2019-20.pdf. Accessed: 27/07/2020

Tsing, A. 2005. Friction: an ethnography of global connection. Princeton: University Press

Varma, S. 2018. Mind the infrastructure gap. National Infrastructure Commission. [Online]. Available at: https://www.nic.org.uk/mind-the-infrastructure-gap/. Accessed: 27/07/2020

Water Briefing (2016) Critics once again question case for Tideway Tunnel. Available at: http:// www.waterbriefing.org/home/company-news/

Water UK. 2019. Dramatic fall in support for water nationalisation after revelations on pension cuts. [Online]. Available at: https://www.water.org.uk/news-item/dramatic-fall-in-support-for-water-nationalisation-after-revelations-on-pension-cuts/. Accessed: 23/07/2020

Whatmore, S. J. And Landtröm, C. 2011. Flood apprentices: an exercise in making things public. Economy and Society. 40(4): 582-610

Whitfield, D. 2020.The Future of Infrastructure Financing. IPPR Progressive Review. 26 (4): 358-366. 